\title{
Teachers' pedagogical content knowledge in teaching word problem solving strategies
}

\author{
Csaba Csíkos $^{1}\left[\right.$ (]) Judit Szitányi ${ }^{1}$ (i)
}

Accepted: 5 December 2019 / Published online: 13 December 2019

(c) The Author(s) 2019

\begin{abstract}
This research addressed Hungarian pre-service and in-service (both elementary and lower secondary) teachers' pedagogical content knowledge concerning the teaching of word problem solving strategies. By means of a standardized interview protocol, participants $(\mathrm{N}=30)$ were asked about their judgement on the difficulty of teaching word problems, the factors they find difficult, and their current teaching practice. Furthermore, based on a comparative analysis of Eastern European textbooks, we tested how teachers' current beliefs and views relate to the word problem solving algorithm described in elementary textbooks. The results suggest that in the teachers' opinion, explicit teaching of a step-by-step algorithm is feasible and desirable as early as in the 1st school grade. According to our results, two approaches (namely, paradigmatic- and narrative-oriented) concerning how to teach the process of word problems solving, originally revealed by Chapman, were found. Furthermore, teachers in general agreed with the approach taken in the textbooks on the subject of what kinds of word problems should be used, and that explicit teaching of word problem solving strategies should be introduced by using simple, routine word problems as examples.
\end{abstract}

Keywords Word problems $\cdot$ Pedagogical content knowledge $\cdot$ Textbooks $\cdot$ Eastern Europe

\section{Introduction}

In this research we aimed to reveal teachers' views and pedagogical content knowledge on teaching elementary students to solve word problems. Teaching how to solve word problems has long been an integral part of mathematics teaching and teacher education in Hungary. The importance of teaching word problems and teaching how students should solve them have not really been questioned or challenged, and the unfavourable results of international educational surveys (IEA, PISA) and internationally comparable results in scientific investigations on word problems (see Csíkos et al. 2012; Verschaffel et al. 2010) drew attention to the role word problems might play in mathematics education in Hungary. Our research focused on pre-service and in-service teachers' pedagogical content knowledge concerning word problems at a time when explicit teaching of the solution steps of a

Csaba Csíkos

csikos.csaba@tok.elte.hu

1 Faculty of Primary and Pre-School Education, ELTE Eötvös Loránd University, Kiss J. altb. u. 40, Budapest 1126, Hungary mathematical problem usually starts as early as in the first grade of schooling. In an attempt to redefine how and why word problems are taught, it is very important to find out how in-service and pre-service mathematics teachers think about word problems.

As Pollak (1969, p. 393) pointed out, students are involved in the application of mathematics "mainly through ... "word' problems". Word problems are often considered a separate genre of mathematical tasks as an addendum to the learning material. According to the nationwide survey of the Committee of Mathematics Education (Hungarian Academy of Sciences 2016), many teachers would eliminate word problems from the first and second grades of public schooling. This view is based on a common sense understanding of what a word problem is and how word problem solution steps are usually introduced in the schools. One reason repeatedly mentioned is that solving word problems requires a relatively high level of reading skills and reading comprehension, and it is not in the mathematics class that such skills and abilities should be improved and assessed.

"Word problems can be defined as verbal descriptions of problem situations wherein one or more questions are raised the answer to which can be obtained by the application of 
mathematical operations to numerical data available in the problem statement" (Verschaffel et al. 2010, p. ix.) This definition involves several types of word problems from mere routine tasks to more sophisticated realistic word problems. Among the several possible roles word problems may play in the classroom, there seems to be an overemphasis on two purposes. Word problems are often used in a way that Palm (2006) described as "many of them are ... merely ordinary school mathematics tasks 'dressed up' with an out-of-school figurative context” (p. 42). Maybe students' superficial strategies in word problem solving are rooted in both our teaching practice and the cultural traditions displayed in the textbooks? Another usual aim in the mathematics classroom (especially in the lower elementary grades) is teaching an algorithm to be followed step by step. Overreliance on either of these two purposes may overshadow other possible functions word problems can (and should) fulfil, e.g., developing self-explanation (see Fonseca and Chi 2011) or shaping a positive attitude towards mathematics.

\section{Word problem solving strategies}

There has been ample evidence that students in their first years of schooling tend to follow a superficial word problem solving strategy (Verschaffel et al. 1997), i.e., a process comprising the steps of finding two or more numbers in the text and selecting and executing arithmetic operation(s); and the numerical results are claimed to be the answer. The truth is that in the vast majority of word problems presented in lower elementary school grades this superficial strategy works fairly well. Furthermore, the roots of mastering such a strategy originate in teachers' instructional strategy, a part of which is teaching word problem solving algorithms.

Word problem solving algorithms are more or less explicitly taught to elementary school children. In Hungarian teacher training textbooks and students' textbooks, several steps of word problem solving are listed and expected to be followed in the classroom. One such example is borrowed from a widely accessible on-line platform containing educational materials for both teachers and students: ${ }^{1}$ reading, understanding, planning (and estimation), drawing (if needed), calculations, verification, answering the question. These steps represent a kind of common understanding of what a word problem solution should look like in written form and how the solution steps are to be scored. While some of the seven (or even eight, if estimation is separated from planning) steps are necessarily present in all kinds of

\footnotetext{
${ }^{1} \mathrm{https}$ ///tudasbazis.sulinet.hu/hu/matematika/matematika/matem atika-4-osztaly/mozgasos-szoveges-feladatok-megoldasa/szovegesfeladatok-megoldasmenete.
}

word problems, others are more specific to certain types of word problems only. For example, sometimes the solution comes not from executing a single arithmetic operation, and often there is no sense in giving any estimation before making calculations. The last two steps may be intended to cover what, otherwise, researchers would label as the interpretation of the solution, but these steps usually prove to be just mechanical activities performed, and in the case of failing to accomplish them students will get a penalty in the form of losing points in the assessment.

Since in their textbook for pre-service elementary teachers Neményi and Szendrei (1997) present a scientifically based description of four general steps of word problem solving, the steps listed above have to be considered as a distillation of pedagogical practice still living among us. Neményi and Szendrei describe four main steps of word problem solving, namely understanding the problem, seeking for a mathematical model and turning the original problem into a mathematical problem, solving the mathematical problem, and interpretation of the mathematical solution. This general four-step model is echoing that of Pólya's (1945) problem solving strategy phases. Understanding the text, preparing a plan for the solution, implementing the plan and checking the results, have become a dominant part of the teaching of mathematics in Eastern Europe.

How and why a general and scientifically-based description of word problem solving (as provided by Neményi and Szendrei 1997) has been transformed into an ordinary and practical to-do list claimed to be 'the' steps of word problem solving is in itself a complex question. It requires the consideration of issues of instructional and assessment methods, dilemmas of equity and even deep philosophical questions of mathematics education. Some of these issues concerning teachers' pedagogical content knowledge are discussed later in this paper, and other issues can be understood from a societal perspective.

Hungarian mathematics education has several facets that can be interpreted in a wider Eastern European context (Csíkos et al. 2019). According to Howson (1980), mathematics education in socialist countries (this is the group to which Eastern European countries belonged for long decades) has three remarkable characteristics: central curricula, word problem content stressing industrial and societal topics, emphasis on talent development and competitions. Here word problems served not only as a training field for arithmetic skills and for following some solution step algorithm, but word problems themselves and especially the way they are instructed were shaped by political and sociological factors. In a Hungarian follow-up study, Vidákovich and Csapó (1998) could use only 64 out of more than 300 word problems that were worded in the 70s because of the politically motivated content elements. 
Other possible and potential functions of solving word problems, such as facilitating general problem solving skills, took a back seat. As a further consequence, teaching and assessing word problems failed to give place for alternative views in either the solvability of a problem or the interpretation of the data and the calculations executed. Naturally, a uniform method of how teaching and assessing (and 'surviving' for both teachers and students) should be done, has developed. The textbooks used currently and in the previous decades bring the implicit and often an explicit message about an expected word problem solving strategy.

\section{Word problem solving strategies in elementary school textbooks}

According to the TIMSS 2011 survey, which explicitly asked fourth grade teachers about their textbook usage habits, the great majority of elementary teachers (international average: 75\%) used textbooks as a basis for instruction. In Hungary, the dominant role of textbooks was marked with a figure of $88 \%$ in this respect (Balázsi et al. 2012). According to van Zanten and van den Heuvel-Panhuizen (2018) the case is similar in lower grades in The Netherlands, and supposedly in Hungary as well. Furthermore, there are some results available on how teachers judge the mathematics textbooks from different aspects (as in a study with Hungarian teachers in Romania by Baranyai and Stark 2011), and there are well-documented differences among word problem types in the textbooks used in different countries (see e.g., Olkun and Toluk 2002; Stigler et al. 1986).

Nevertheless, how word problems are presented in mathematics textbooks, and the way in which the solution process is shown and illustrated, indicate both the current practices teachers are thought (or expected) to follow and textbook writers' suggestions about how they would present and solve those word problems.

At the start of teaching school mathematics, teachers use situations expressed in words to represent an arithmetic operation. In this period the basic purpose of introducing word problems is only understanding the structure of an operation, as illustrated in Fig. 1, demonstrating the idea of multiplication as repeated addition.

Later when pupils are already acquainted with arithmetic operations, the main purpose of using word problems is to make children recognize and understand what the text describes and select a suitable model for problem solving. At the same time, explicit steps of a word problem solving method are provided in a popular Russian textbook.

The way in which the steps of the word problem solution are provided in Fig. 2 raises several issues. The explicitness of writing the solution steps in bold, and listing them in a consecutive order, have a strong message for both the

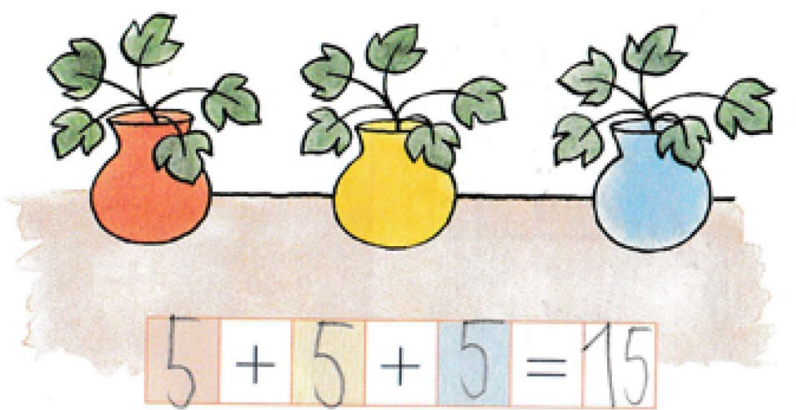

Fig. 1 Example of a word problem illustration for visualizing a simple arithmetic operation (Lehotanová 2013, p. 23)

teacher and the students. One strong message is that besides practicing an arithmetic operation dressed-up in familiar content, teachers and students are invited to do some extra work beyond mere calculation, thereby acting as required in the solution process of a word problem. An even stronger message may be that teachers and students are invited to solve all arithmetic word problems by following all the steps displayed in the textbook. Such a linear solution process may at the same time dissuade the teachers and students from applying a modelling cycle as described by Borromeo Ferri (2006).

The metacognitive components of students' thinking necessarily develop while following the prescribed steps of the solution. They are invited and required to plan, monitor and evaluate their own thinking processes. These metacognitive processes have for long decades been recognized and addressed in mathematics education, mainly due to the pioneering work of the Hungarian György Pólya (1945). Pólya has a real cult among Hungarian mathematics educators, but, as we hypothesize, his maxims concerning problem solving may be misinterpreted when teaching and learning mathematical word problems in the elementary school years.

Having reviewed Eastern European textbooks of Romania, Russia, Slovakia, Croatia and Hungary, we found similarities in these books; they are as follows.

1. As it can be observed in Fig. 2, usually two birds are killed with one stone. It is not only the actual solution of the word problem that is presented, but also the demonstration of the algorithm which can later be used in general in solving word problems.

When teaching the algorithm, two important factors must be taken into consideration. Firstly, it seems to be of doubtful validity to combine the processes of understanding and solving the word problem with teaching and memorizing an algorithm of the solution process. Secondly, choosing a suitable problem is essential, since if the task is too easy, the child may have difficulty in understanding why following a 


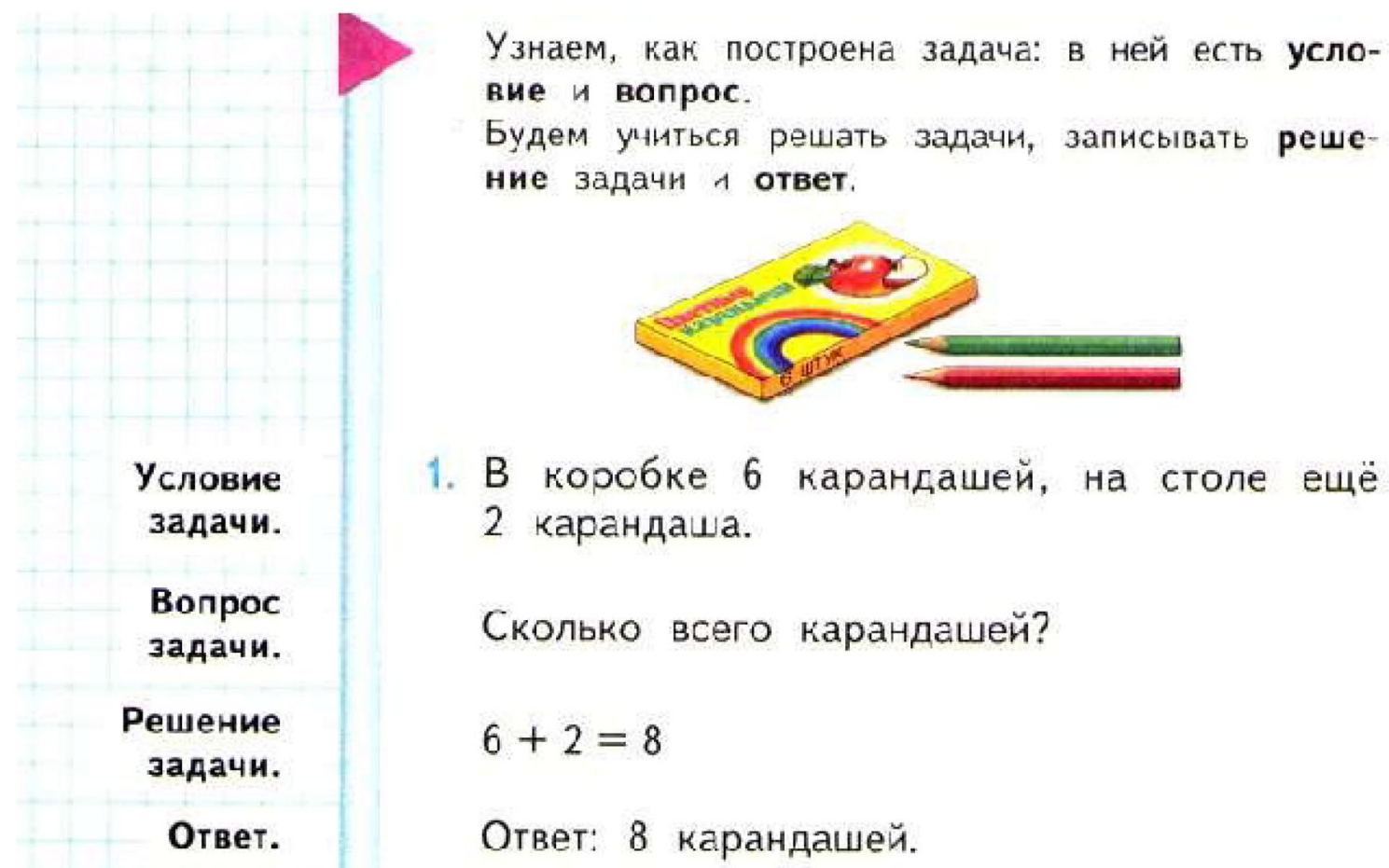

Fig. 2 Explicit teaching of the steps of word problem solving in a Russian textbook (Moro, Volkova and Stepanova 2011, p. 88). Expressions on the left-hand side of the figure in bold, from the top to the bottom, are as follows: conditions of the task, question (of the task), problem solving, and answer. The word problem itself is pre-

prescribed algorithm is necessary (there are 8 pencils and that's all).

2. In most of the textbooks, a component of the solution algorithm of a word problem is the depiction of the text in some manner, e.g., by making a drawing. Making a drawing can be essential in solving word problems. The capability of making a drawing that suits the task is also the result of the learning process. However, the manner and the extent to which help is provided by the teacher are crucial points. As suggested by Csíkos et al. (2012), it is not making a drawing that is in itself fruitful but building metacognitive knowledge components on a possible repertory of drawings and about the conditions under which those drawings support the solution process.

3. An essential part of teaching the solution algorithm is checking the result.

Checking the result can be accomplished in two ways when solving a word problem. On the one hand, it provides an opportunity to check the operation setup based on the model by means of executing the inverse arithmetic sented as follows: "It is known that a task consists of conditions and an answer. We will learn how to solve problems and how to answer them. There are 6 pencils in the box and 2 others on the table. How many pencils are there together?"

operation, and on the other hand checking may refer to a different understanding of the text.

4. When we examined the textbooks, we found that the algorithm of the solution of the word problem can be observed as early as in the first school grade in the countries examined.

5. We could see a number of word problems in the textbooks which may be understood only with difficulty by the children, without the teacher's help and conducting a discussion in the classroom. The first- and second-grade students may not possess the reading comprehension required to understand and solve the word problems by means of individual work.

Since textbook word problems are of a specific kind, teachers have an important task in handling those word problems and in fulfilling a desirable word problem teaching practice. Therefore, it is worth looking at teachers' pedagogical content knowledge concerning the teaching of word problems. 


\section{The role of teachers' pedagogical content knowledge in teaching word problem solving strategies}

Studying the issue of when and how to introduce word problem solving strategies in elementary school, it is important to find out what teachers think and know about these issues. They may agree or disagree with what textbooks intend to propose, and it is the teachers' experience and pedagogical content knowledge that certainly influence their textbook usage.

Teachers' pedagogical content knowledge (PCK) is usually described by means of the Shulmanian sense of the term (Shulman 1986). Among the knowledge components necessary for anyone to be a successful teacher, one form of teachers' knowledge is of utmost importance, namely the knowledge form that is built on the content knowledge but goes beyond that by powerful analogies, illustrations, demonstrations, etc., in order to make the content to be learnt comprehensible to others. Therefore, mathematics teachers must possess-beyond a high level of mathematical common content knowledge (Ball et al. 2008) - further knowledge components: an "armamentarium ... of representations some of which derive from research whereas others originate in the wisdom of practice" (Shulman 1986, p. 9). According to Hill et al. (2008), teachers' knowledge about what makes a problem difficult for a student highly depends on the teacher's level of mathematical subject-matter knowledge.

As for word problems, it is clear that teachers must not only have the necessary knowledge to solve the tasks, but they must have further knowledge components, a repertoire of word problem solving strategies that are somehow comprehensible to the students. As Shulman (1986, p. 9.) rightly claimed, "there are no single powerful forms of representations", and mathematics teachers' pedagogical content knowledge regarding word problems should adopt different solution strategies and techniques (and the corresponding specialized content knowledge). An example of how different teaching strategies evolve during a mathematics lesson among first grade students can be found in the paper by Rowland et al. (2005). Their observation with a pre-service teacher nicely illustrates how important flexibly changing the current teaching strategy can be.

Teachers' classroom practices for teaching word problems were studied by Chapman (2006), who claimed that there had been only a few studies conducted on pre-service teachers' difficulties with word problems, and there is a lack of research focus on how pre-service teachers handle the contextual factors of word problems, i.e., the extent to which realistic considerations are to be taken into account. Verschaffel et al. (1997) found a serious lack of realistic considerations among pre-service teachers when solving realistic tasks. This lack of realistic considerations was detected by means not only of their solutions to such problems, but also by their evaluation of different possible solution types. Therefore, pre-service teachers may not always be right in assessing the difficulty of different word problems.

According to Shulman (1986), finding out why learning a topic is easy or difficult is an integral part of the PCK. Due to Chapman's (2006) study, two types of orientations can be distinguished with respect to how teachers view word problems. Teachers who adopt a paradigmatic-oriented approach will usually blame the realistic context of word problems as a main barrier to providing a mathematical solution. In contrast, teachers who follow the so-called narrative-oriented approach pay much attention to the psychological factors of the solution. They focus on students' attitudes, motivation and potentially different critical interpretations of the text. According to them, failures should not be attributed mainly to a lack of mathematical skills but rather to a lack of meaningfulness.

It has been reassured in several empirical and comparative studies that drawings (both the type of drawing and the process of making drawings in the classroom) play a very important role in shaping students' beliefs about and solution strategies for word problems (see e.g., Willis and Fuson 1988; Depaepe et al. 2010). As for the two main teaching approaches defined by Chapman (2006), the main challenge facing the pragmatic-oriented approach is to find the appropriate (and almost always schematic) drawing that should definitely display some kind of mathematical content, whereas teachers following the narrative-oriented approach may seek a variety of possible drawings each with their own possible advantages in the solution process. In a design experiment among 3rd grade students, Csíkos et al. (2012) found the latter approach beneficial in terms of both yielding better performance and inducing possible long-term effects on students' metacognitive knowledge.

Finally, another important aspect of teachers' pedagogical content knowledge is addressed in the current study: how they assess students' word problem solving activities. As Verschaffel et al. (2010) emphasized, how students' mathematical performance is assessed has a strong influence on teaching practice. They revealed that current summative evaluation practices have several characteristics that are not in line with what researchers would find fruitful for assessing higher-order thinking skills. It is highly probable that teachers' formative assessment techniques applied in classroom settings are in line with how their students will be assessed in high-stakes tests. Independently of the current high-stakes testing practices, it is worth finding out how teachers in the classroom assess (more concretely, score) the students' solutions provided for word problems.

In the current investigation we focus on pre-service and in-service teachers' pedagogical content knowledge 
concerning word problems, including whether they teach uniform solution strategies or algorithms, how they assess students' solutions, what is their insight about making drawings during the solution process, and what they would do if students were 'ruining' a word problem by finding the content of the word problem incomplete or unclear. Besides exploring teachers' PCK, further thinking components of similar importance (such as beliefs, views) were addressed. According to Pehkonen and Pietilä (2003), beliefs and views are often implicit knowledge components that may have an emotional component as well. In-service and pre-service teachers' knowledge of word problems can often be implicit in the sense that they have not necessarily elaborated their views verbally before being asked about them. Our research questions concern pre-service and in-service teachers' pedagogical content knowledge about teaching word problems.

1. According to teachers, when is it suitable to start teaching an algorithm for solving a word problem?

2. Which steps do teachers focus on during the solution of the word problem? Do they follow a paradigmaticoriented or narrative-oriented approach?

3. How do teachers judge the role of drawings when solving word problems?

4. How do teachers take realistic considerations into account in elementary textbook word problems?

\section{Methods}

\subsection{Sample}

In this research, 30 pre-service and in-service teachers were involved. The subsample of elementary teachers was recruited from among both novice and expert teachers, and lower secondary mathematics teachers comprised the fourth subset. Therefore, our respondents belong to four groups: elementary teachers with less than 5 years of experience, elementary teachers with more than 5 years of experience, lower secondary mathematics teacher in grades 5-8, and pre-service elementary teachers. Respondents were recruited from the capital of Hungary and from a countryside village. Basic demographic characteristics of the sample are presented in Table 1.

The students were second year students of Eötvös Loránd University Faculty of Primary and Pre-School Education. Their studies already included one semester of mathematics teaching methodology, where the solution of word problems was part of the curriculum. In their case, the Budapest/countryside distinction is not relevant.
Table 1 Basic demographic characteristics of the participants

\begin{tabular}{lllc}
\hline & Capital & Small town & Total \\
\hline $\begin{array}{l}\text { Teacher with less than 5 years of experi- } \\
\text { ence }\end{array}$ & 3 & 3 & 6 \\
$\begin{array}{l}\text { Teacher with more than 5 years of } \\
\text { experience }\end{array}$ & 5 & 7 & 12 \\
$\begin{array}{l}\text { Teacher in grades 5-8 } \\
\text { Pre-service teacher }\end{array}$ & 3 & 3 & 6 \\
\hline
\end{tabular}

\subsection{Interview}

In this research we used the method of standardized, individual interviews. Each interview was carried out based on a strict protocol that contained 26 questions, and lasted for 12-27 min per person. The interviews based on the protocol were prepared and supervised by the same person throughout in order to avoid any possible anomalies due to questioning and meta-communicative style. ${ }^{2}$

Based on a comparative document analysis of several Eastern European textbooks, an interview-protocol was developed. We were especially curious about the very first appearances of word problems in the textbooks. Having observed that there seems to be a rather uniform introduction of word problems as a genre in eastern European textbooks, we aimed to reveal teachers' views about teaching word problems. We aimed to explore teachers' views about the first appearance of word problems in the textbooks, and with this intention we formulated more general questions about word problems (definition, attitude and perceived difficulty) as well as some more specific questions concerning the teaching methods, including how they assess students' problem solving.

During the interview, specific word problems from textbooks were analysed, and we also asked questions regarding the teaching habits of the respondents. Besides, we asked for the solution of an open-ended word problem ("Friends", see Sect. 6.5 and the "Appendix" for a detailed description of the task) from the often-replicated Flemish study of 'problematic' word problems (Verschaffel et al. 1994).

The questions of the interview were grouped around the following topics:

- Approaches to the definition of word problems.

- Attitude towards and judged difficulty of teaching word problems.

- The first steps of teaching how to solve word problems.

\footnotetext{
${ }^{2}$ We wish to thank teaching assistants Fanni Birtalan, Borbála Károlyi, Tímea Varga and Anna Rácz for the transcription of the interviews.
} 
Table 2 Number of participants in each subgroup belonging to the paradigm approaches as described by Chapman (2006)
Paradigm-oriented approach Narrative-oriented approach

\begin{tabular}{lll}
\hline Teacher with less than 5 years of experience & 3 & 3 \\
Teacher with more than 5 years of experience & 7 & 5 \\
Teacher in grades 5-8 & 3 & 3 \\
Pre-service teacher & 2 & 4 \\
\hline
\end{tabular}

- Methods and techniques used in teaching how to solve word problems.

- Participants' own solutions to a word problem.

The questions of the interview refer to (1) the optimal school grade when explicit word problem solving strategy should be introduced, (2) the debate of how difficult a word problem should be in order to justify the use and teaching of explicit multi-step solution strategies, (3) the role of visual aids in the textbooks, and (4) how teachers react when students provide unexpectedly realistic solutions to a word problem that was seemingly designed as a pseudo-realistic routine word problem (as described by Csíkos and Verschaffel 2011).

The questions of the interview protocol are presented in the Appendix. In the evaluation procedure, several quantitative variables have been defined according to and in line with the interview questions. Most of them are of dichotomous nature, e.g., whether the respondent always requires students to formulate the answer in a full sentence or not. In some cases, answer codes with more than two responses were developed, as in the case of the Friends task at the end of the interview. By means of defining mainly dichotomous quantitative items, we aimed to assure the objectivity of our data analysis and interpretation.

\section{Results}

\subsection{Approaches to the definition of word problems}

At the very beginning of the interview, we wished to clarify the definition of a word problem and narrow down the scope of word problems to routine word problems. Therefore, first we asked the respondents to give a definition of the concept of word problem.

Respondents approached the question in two distinctively different manners. On the one hand, they might have thought that each problem we give to pupils expressed in words, is considered a word problem.

Bori, elementary teacher: Anything, which also contains letters, not only numbers. When there are several instructions and an exclamation mark.
The other approach also contained the expectations concerning the solution algorithm of word problems.

Edit, elementary teacher: A calculation task where the task is preceded by text information. The tasks and text must be understood and written down in signs of the mathematical language. At the end of the solution process, provide an answer to the problem.

These two types of approaches are present in all groups as presented in Table 2 .

Besides the overall categories according to Chapman, further dichotomous variables were derived from the interviews. One such dichotomous variable refers to whether participants considered mathematical word problems and mathematical problems given in words to be the same. Thirteen of the respondents felt there is a sharp distinction between a word problem and a problem given in words. Another aspect among which participants can be split into two groups is whether the term 'operation' appeared in their definition or not. In 13 cases (43.3\%) the word 'operation' appeared in the definition, which might indicate that these respondents considered only word problems that can be solved with an operation.

We made clear that in the following we would focus on the solution of routine word problems.

\subsection{Attitude towards and judged difficulty of teaching word problems}

Seven questions of the interview concerned this topic. Participants usually considered teaching word problems difficult. 23 respondents said this topic was or would be very difficult to teach. The difficulty was attributed to two factors. On the one hand, they thought that students' everyday conceptual understanding is problematic, and on the other hand they did not consider this problem as either being mathematical or to be developed in mathematics.

Erzsi, elementary teacher: The problem is they have no everyday experience, and they also have conceptual deficiencies.

Detti, elementary teacher: The problem rather lies in comprehension, the pupils freeze when they hear they have to solve a word problem. Girls are more prone to 


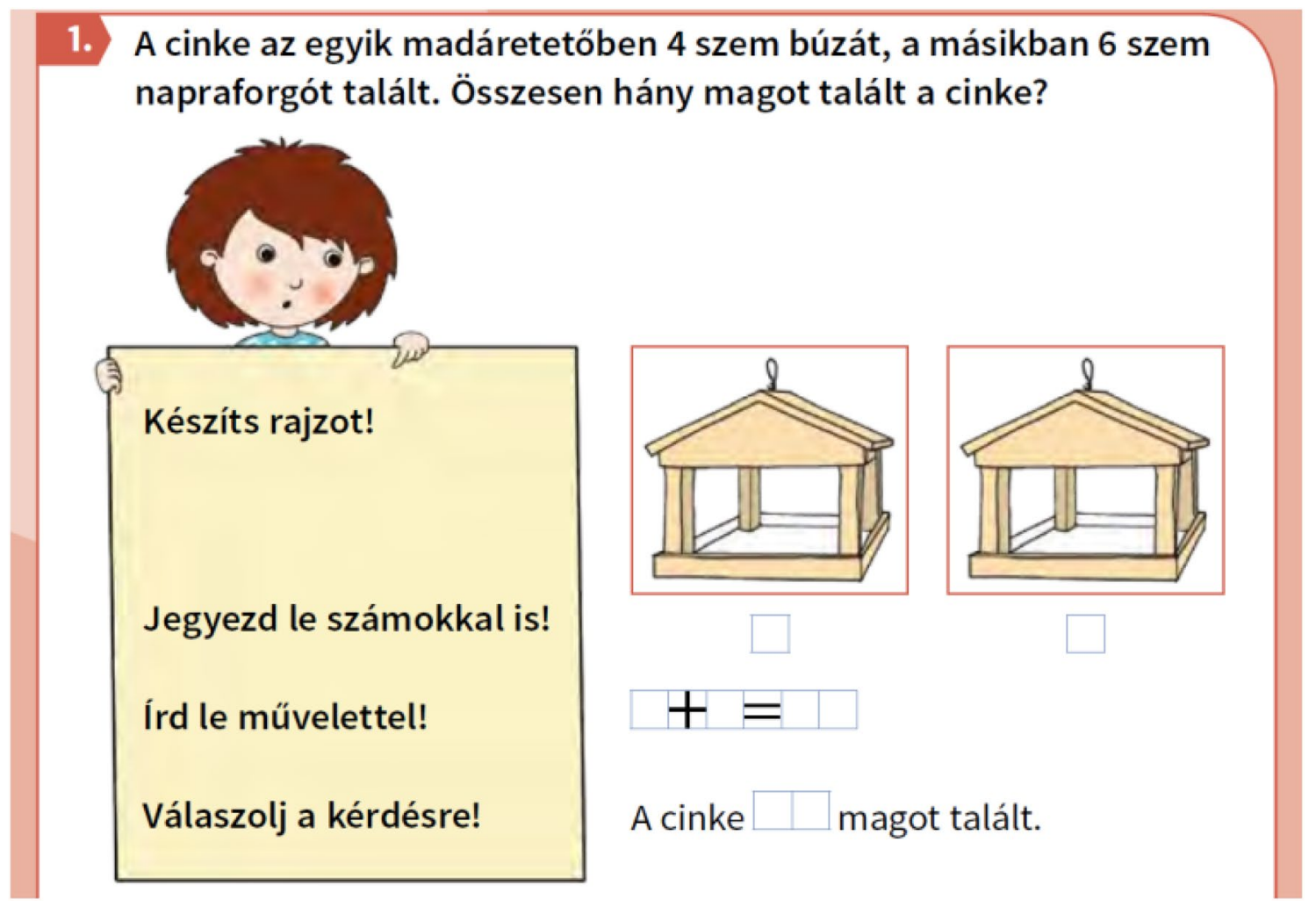

Fig. 3 The very first word problem in a Hungarian first grade students' textbook (OFI 2016, p. 102). Translation of the word problem text: The titmouse has found 4 wheat grains in one of the bird feeders, and 6 sunflower seeds in the other. How many seeds has the

getting scared...Children do not know tales, therefore texts from tales do not mean anything to them. In addition, there are many unknown words in the texts.

Teachers see several difficulties in how to code the word problem in the language of mathematics.

Gabi, elementary teacher: I think children understand this with great difficulty, for them this is an abstract thing to prepare a plan for the solution, write down the calculation and check the answer. These restrict children, they are confused, get scared and panic, and they mess up or miss something.

Gabi, lower secondary teacher: My class has just written a test in word problems, and I believe we were well prepared, as we had exercised typical tasks. However, when the pupils had to face the same problem with different numbers, they made mistakes and could not apply the techniques they had learnt.

András, elementary teacher: There is a problem that we cannot influence: word problems are often a testing tool in competitions and entrance examinations. There is huge pressure in teaching that pupils must be good titmouse found altogether?". Translation of the instructions written in bold from the top to the bottom are as follows: make a drawing, write down with figures, write down with an operation, and answer the question

at that. It is very difficult to provide universal models which work in all kinds of text environments.

Judit, elementary teacher: When the algorithm is clear and well-prepared, there is no problem.

It is worth mentioning that according to seven participants the solution of word problems is not difficult. Six of them are elementary teachers and one of them is a lower secondary mathematics teacher. Six of them gave a definition in answer to the question "How do you define the concept of word problem?"- an answer that restricted the meaning of word problem to arithmetic operations dressed up in a text. They probably restrict their teaching duties to word problems with straight wording that can be solved by executing one arithmetic operation.

\subsection{The first steps of teaching how to solve word problems}

The third part of the interview dealt with an analysis of a word problem. The problem illustrated in Fig. 3 is the very first word problem in the 1st graders' new generation 
textbook in Hungary which intends to introduce the solution algorithm for word problems.

We consider the wording of the problem challenging, as it does not define whether there can be other seeds than wheat or sunflower in one or both of the feeders, or whether the titmouse has found seeds elsewhere, not only in the feeders. This kind of 'ruining' of the word problem is similar to that of Freudenthal's idea as cited by Greer (1997). The phenomenon of "didactic contract" created by Brousseau (see Verschaffel et al. 2010) is continuously shaped and strengthened by such tasks in the world of the classroom social environment.

The instructions on the left of the drawing (prepare a drawing, put down in numbers, describe with an operation, answer the question) can be followed with difficulty, posing new problems beyond the word problem, which the children have probably solved by heart.

Ágnes, elementary teacher: I don't like it. It is confusing in 1st grade that there are two texts next to each other. I think the instructions such as draw, write it down with an operation, answer, should not be written there, because this is my (the teacher's) request. I would not start teaching the algorithm. The pupil still cannot make a distinction between the task and the instructions belonging to the algorithm.

Drawing the seeds in the feeder seems unnecessary, as in the task pupils have to depict the data and then 'read back' the numbers from the drawing.

András, elementary teacher: I think this problem does not require a drawing, especially since the number, the plus sign are there, the result is 10 and that's it. I think it is unnecessary to draw here, it is not a challenge for pupils.

Another objection to the task is that its reality is questionable.

András, elementary teacher: I think most of the word problems are useless. This is why I use word problems created by myself, still it is important that the pupils enjoy it. Who cares how many this and that in total, and that the titmouse first eats this and then that? The child is not motivated. There are enough problems the children have to solve in their own lives.

According to one interpretation of realistic tasks, besides that the things in the problems should be ordinary and realistic, they also need to be meaningful and experience based, compared to tasks that are only "cover stories" for irrelevant drills (English 2003). However, participants' opinions were somewhat different. 20 persons $(66.7 \%)$ considered the task totally suitable for teaching the algorithm of word problems. However, eight of them noted that it might be necessary to clarify the meaning of wheat, sunflower and seed beforehand.

One third of the respondents considered the task unsuitable. Four of them said it contained too much information. Five of them were of the view that the words wheat-sunflower-seed might not be familiar to children. Nonetheless, their reasons given for their views are not always the ones with which researchers would agree.

Gabi, lower secondary mathematics teacher: How shall I add wheat and sunflower? We always say we do not add apple with pear. In 5-8 grades we can only add identical expressions. We cannot add sunflower to wheat, because they are not identical.

Only one teacher said that the wording of the task is not accurate.

Judit, elementary teacher: It is not written that there are altogether two bird feeders. The question is not accurate.

Two thirds of the respondents did not question the truthfulness of the text. This ratio elevates to $76 \%$ among the countryside respondents.

Anna, elementary teacher: When the class loves nature and feeds the birds, this is realistic. I think it is realistic, because they have seen all kinds of seeds in the feeder here. It is not strange to them.

16 respondents (53\%) believed the drawing was helpful in the solution of this task. Meanwhile $73 \%$ of respondents said a drawing is always necessary in the solution of a word problem. In light of the differences between $53 \%$ and $73 \%$, one may conclude that there should have been a better drawing attached to the very first word problem children encounter in their first school grade.

$83 \%$ of respondents believe a full sentence answer is always necessary, while only $68 \%$ think it is necessary for this task as well.

Ágnes, elementary teacher: In general, it is necessary, because it strengthens the feeling that this is a real problem. Then I abstract it, and then place it back in the real environment. Then I check whether it is realistic. Here I do not think it is good that the pupils only have to insert the numbers.

Anna, elementary teacher: In the beginning I do not expect a full textual answer.

In Hungary, and based on the textbook comparisons, in Eastern Europe, too, answering in complete sentences is an important tradition. Only five respondents said that they would not expect a textual answer from the children, and four of these five respondents were pre-service teachers. It 
seems this tradition is strongly related to high-stakes assessment tests introduced in Hungary, where many points are lost when there is no textual answer provided. It seems that in-service teachers consider preparation for assessment to be important, while pre-service teachers do not (yet).

\subsection{Methods and techniques used in teaching how to solve word problems}

The next group of questions concerned teaching experience. These questions were not asked of the pre-service teachers. It is important when and how we start teaching any algorithm relevant to word problems. In our view, explicit teaching of solution strategies is questionable, since young children may mix up two things: solving a problem and knowing by heart the steps of the solution process. Typically, word problems in first grade can be solved in one step by means of executing one arithmetic operation. It is difficult to explain why a stepby-step algorithm is needed when the child already knows the answer almost immediately after having read the text.

$79 \%$ of the respondents reported that they start teaching an explicit algorithm already in the first grade, and for this purpose $91 \%$ of them choose a simple word problem with straightforward wording, which can be solved with one operation, calculated mentally.

Ildikó, elementary teacher: Although I teach it already in the second semester of the first grade, we usually play and do not calculate. E.g., they stand up when they have to add.

Only two teachers formulated a radically different opinion.

Ágnes, elementary teacher: I start with a more complex problem, in higher grades. It only makes sense then, because before that they do not understand why they have to do it.

András, elementary teacher: When I started teaching I thought I would have to start with the simple ones, but I realized that a word problem really has to be a problem. When the pupil looks at it and they can solve it immediately, they do not feel that any algorithm makes sense. When they look at it and say 10 , but for the teacher's sake I will write an open sentence, the whole thing becomes an end in itself.

We asked by means of what instructional techniques they help their students in word problem solving. Two things could be distinguished clearly: text highlighting (48\% indicated) and the support of reading comprehension.

Ildikó, elementary teacher: They underline essential data with a pencil.
We asked the respondents to map their assessment habits by scoring the solution of the following task as if it was in a test: "Betti and Dóri invite their friends for a party. On each tray there are 3 cheese, 5 salami and 3 ham sandwiches. How many sandwiches are altogether on the 5 trays?" Participants were free to use any scoring system from dichotomous 0-1 to a more refined scoring system.

The respondents gave 5.2 points on average for the correct solution. The minimum was 3 (two for the calculation, one for the textual answer), the maximum was 10 . Two thirds of the respondents gave the points according to the steps of an expected algorithm. From the steps of the algorithm, they considered the following especially important: writing down the data, writing an open sentence, calculation, textual answer. The open sentence as a model was highlighted in half of the answers.

Bogi, elementary teacher: In the solution plan we always write an open sentence, and there might be several solutions. We write it down in a manner that allows for several solutions.

The question of textual answer proved to be especially important. We also asked whether they gave a point for the textual answer even when the calculation and the solution of the task were wrong. 19 respondents said they would give a point. Their reasons were as follows. They either do not want to punish the student twice for a mistake, or as one elementary teacher dared to confess her confusion, "It is a dilemma, because in principle it would be fair to give a point. Therefore I do not know."

We asked what other models they showed children to solve word problems. Our question caused a little confusion, and not many ideas arose. Drawing sections were mentioned by three elementary teachers, trial and error by two lower secondary math teachers, and charts by one elementary teacher as possible models in solving word problems.

\subsection{Participants' own solutions to a word problem}

The interview ended with the solution of the word problem from Verschaffel et al. (1994). "Karcsi and Gyuri organize their birthday party together. Karcsi invited 5 children, Gyuri invited 6 children. How many children were there at the party?"

This task is a typical open-ended task, as the solution is not one determined number. There are several factors you can take into consideration during the solution, which shows that the "look for the number data and then link them with the appropriate operation" strategy is not effective. Were there any children who were invited by both organizers? Did Karcsi and Gyuri participate in the party? Did all the invited children actually go to the party? 
Table 3 Solution provided by participants to the "Friends" word problem

\begin{tabular}{lllllc}
\hline & $\begin{array}{l}\text { Teacher with less than } \\
\text { 5 years of experience }\end{array}$ & $\begin{array}{l}\text { Teacher with more } \\
\text { than 5 years of experi- } \\
\text { ence }\end{array}$ & $\begin{array}{l}\text { Teacher } \\
\text { in grades } \\
5-8\end{array}$ & $\begin{array}{l}\text { Pre- } \\
\text { service } \\
\text { teacher }\end{array}$ & Total \\
\hline Solution $5+6=11$ & 5 & 5 & 0 & 4 & 14 \\
Solution $5+6+1+1=13$ & 0 & 7 & 4 & 0 & 11 \\
At least 6, at most 11 & 0 & 1 & 1 & 1 & 3 \\
Complete solution & 0 & 0 & 1 & 1 & 2 \\
\hline
\end{tabular}

We asked the respondents to solve the word problem in a manner they would expect their 2 nd grade pupils to employ. We wondered how the participants would interpret this task. If they did not recognize the trap in the task, we asked whether they would modify the solution in higher school grades. With this instruction, we softly guided them to reconsider the problem. Table 3 presents the solution according to teaching grades and experience. There were four categories defined, and all respondents' answers fell into one of them. The most sophisticated, realistic answer went further than merely executing arithmetic operations with the numbers of the text, and opened up the possibility of different possible solutions. So the 'complete solution' contained one or more numerical answers (as in the other three answer categories), and additionally a remark or hesitation on the existence of a one-and-only numerical answer.

According to Table 3, all subgroups of participants provided different answer patterns to this question. Please note these solution patterns are not inherently theirs but these are the kinds of answers they would expect from 2nd grade students. Unfavourably, from these answers it can be hypothesized how their students will behave when confronting realistic word problems in school.

\section{Discussion}

\subsection{Novelty}

We explored Hungarian pre-service and in-service teachers' pedagogical content knowledge on how textbooks may have shaped and are still influencing the practice of teaching word problem solving strategies. While our study can be considered in some sense the replication of results from both the Leuven researchers and Olive Chapman, we think that some new explorations took place here. First, we revealed that, according to the great majority of the participants, explicit teaching of word problem solving strategies should start not only rather early in the elementary school, but also by means of using simple, one-step routine tasks for illustrating the main steps of an expected algorithm. Second, several possible scoring methods were revealed, and almost all of them included the need for scoring the mere existence of a textual answer, more or less independently of its mathematical content. Third, a variety of helping techniques appeared in the answers from underlining essential parts of the text-leaving the question open of a possible vicious circle: how do we know which parts are essential? - to playing activities and making drawings.

\subsection{Limitations}

Having addressed the possible socio-cultural context of our study, we nevertheless consider that although the participants are Hungarian, the results may be generalized to a wider population. Textbooks have their prime role in elementary mathematics education, and as stated by Stigler et al. (1986), citing a Soviet-American textbook comparison study, "there is a bias in the American textbooks toward presenting the problems that American children find easiest to solve" (p. 166) Word problems are selected and presented in the textbooks in accordance with the language and cultural constraints (Fan et al. 2018) as well as reflecting the traditions of a country's mathematics education. Nonetheless, the challenges and dilemmas elementary teachers face when teaching word problems may be more or less global with respect to improving students' mathematical thinking.

The interview method formed another constraint regarding the sample size, taking account of our aim that it was the same interviewer who conducted all the interviews. Our data analysis is overwhelmingly of qualitative nature aiming to address some important phenomenon. Another stratum of our sampling (capital-village dichotomy) was found to be important in one aspect only, i.e., the suitability of the content element in the word problem children encounter for the very first time in their first grade of schooling.

\subsection{Practical conclusions}

How word problems and word problem solving strategies are introduced in the textbooks is necessarily built on an assumed consensus on these questions. In general, Hungarian elementary teachers use textbooks as a basis for their instructional practice, therefore, the consensus on teaching of word problems and word problem solution strategies can be further reassured by the instructional practice. There are 
at least two components of this consensus that should be reconsidered in order to activate and promote teachers' specialized content knowledge (Ball et al. 2008) on teaching word problems. One such knowledge component is handling linear versus cycled solution processes. Teachers' current views support the linear solution model of word problems where several consecutive steps are to be followed. Teachers generally agree that such a linear solution method should be introduced with simple routine tasks and at an early stage of learning mathematics. Another important specialized content knowledge component is making a distinction between checking the solution by means of executing an inverse operation or by means of retelling the story of the word problem, substituting the proposed numerical answer. There is also a pedagogical content element that should be reconsidered: the assessment practice of word problem solutions. Teachers have diverse opinions about how to score word problem solutions, and they seem to emphasize in their scoring habits how students followed the prescribed linear solution method.

\subsection{Further research questions}

We consider it crucially important to further study the debate concerning the question of whether any explicit teaching of a word problem solving strategy should use simple, onestep routine word problems as illustrations, or more complex and realistic word problems, which may provide justification for introducing explicit metacognitive knowledge components in word problem solving. Another dilemma raised by the current investigation concerns the appropriate timing of introducing explicit word problem solving strategies. Besides the timeline issue, another possible question would address which steps of a traditional, linear solution methods should be introduced first and which ones later.

Acknowledgements Open access funding provided by Eötvös Loránd University (ELTE). This research was supported by the Research Center on Early Childhood Education at the Faculty of Primary and Pre-School Education, ELTE Eötvös Loránd University, Hungary. We are grateful - for their altruistic help in the collection of Eastern European mathematics textbooks— to Szilárd András, Zuzana Nagyová Lehocká, Anna Shvarts and Gordana Stankov.

Open Access This article is licensed under a Creative Commons Attribution 4.0 International License, which permits use, sharing, adaptation, distribution and reproduction in any medium or format, as long as you give appropriate credit to the original author(s) and the source, provide a link to the Creative Commons licence, and indicate if changes were made. The images or other third party material in this article are included in the article's Creative Commons licence, unless indicated otherwise in a credit line to the material. If material is not included in the article's Creative Commons licence and your intended use is not permitted by statutory regulation or exceeds the permitted use, you will need to obtain permission directly from the copyright holder. To view a copy of this licence, visit http://creativecommons.org/licenses/by/4.0/. 


\section{Appendix}

1. I requested this meeting because we are carrying out a research project to map difficulties related to the solution of word problems.

a) How do you define the concept of a word problem?

b) Can you see a difference between the two concepts: a problem expressed in word, and word problem?

In the following, we will focus on the solution of routine word problems, when the pupils know they are solving a word problem.

2.

a) How difficult do you consider the teaching how to solve word problems compared to other topics in mathematics?

b) What do you think the causes of the difficulties are?

c) When do you think it is useful to start dealing with word problems?

d) How do you start teaching the topic?

3. In the picture you can see the word problem which introduces the teaching of the topic in one of the first grade textbooks. Do you know this task?

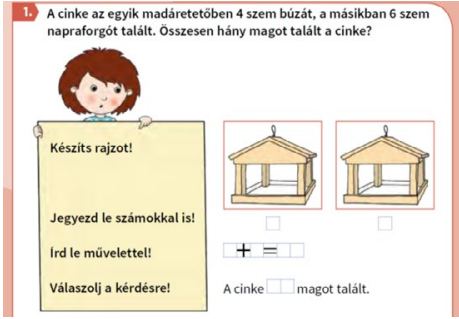

a) What is your most important impression of this task?

b) Some say the task is not exact enough. What do you think they meant by that?

c) Do you expect further confusion or incomprehension from the children?

d) Let us discuss how lifelike the text is. Meanwhile let us take into consideration that the obvious goal of the authors was to teach the solution process of a word problem.

e) How do you think the solution of this task is helped by the started drawing?

f) Can you agree that in solving a word problem a drawing is always necessary?

g) Can you agree that a text answer is always necessary?

a) How and when do you start teaching the solution process of word problems?

b) Do you start teaching the algorithm with a one-step problem which can be calculated even mentally?

c) What steps do you consider indispensable?

d) How do you make pupils aware of these steps?

e) Does the number of steps increase with the progress of years?

f) What techniques do you use to help to find the data?

g) What models do you show children to find the links within the text?

5 .

Let us suppose that the following task is in a $2^{\text {nd }}$ grade test:

Betti and Dóri expect their friends for party. On each tray there are 3 cheese, 5 salami and 3 ham sandwiches. How many sandwiches are altogether on the 5 trays?

a) Would you put any illustration next to the task?

b) How many points would you give for the solution of the task? Is this how you act in general?

c) How would you break down the points of the task to parts?

d) Do you give a separate point when the child answers with text? If the solution is wrong, do you still give a point for the text answer?

a) Solve the word problem as if you expected it from a second grade pupil!

Karcsi and Gyuri organize their birthday party together. Karcsi invited 5 children, Gyuri invited 6 children. How many were there at the party?

b) Now solve the problem as you would expect it from a pupil in $3^{\text {rd }}$ or $4^{\text {th }}$ grade! 


\section{References}

Ball, D. L., Thames, M. H., \& Phelps, G. (2008). Content knowledge for teaching: What makes it special. Journal of Teacher Education, 59, 389-407.

Balázsi, I., Balkányi, P., Bánfi, I., Szalay, B., \& Szepesi, I. (2012). PIRLS és TIMSS 2011. összefoglaló jelentés a 4. évfolyamos tanulók eredményeiröl. [PIRLS and TIMSS 2011. Summary report on the results of fourth grade students]. Budapest: Oktatási Hivatal.

Baranyai, T., \& Stark, G. (2011). Examination of mathematics textbooks in use in Hungarian primary schools in Romania. Acta Didactica Napocensia, 4, 47-58.

Borromeo Ferri, R. (2006). Theoretical and empirical differentiations of phases in the modelling process. ZDM Mathematics Education, 38, 86-95.

Chapman, O. (2006). Classroom practices for context of mathematics word problems. Educational Studies in Mathematics, 62, $211-230$.

Csíkos, C., András, S., Rausch, A., \& Shvarts, A. (2019). Mathematical learning and its difficulties in Eastern European countries. In A. Fritz, V. G. Haase, \& P. Räsänen (Eds.), International handbook of mathematical learning difficulties (pp. 145-163). Cham: Springer.

Csíkos, C., Szitányi, J., \& Kelemen, R. (2012). The effects of using drawings in developing young children's mathematical word problem solving: A design experiment with third-grade Hungarian students. Educational Studies in Mathematics, 81, 47-65.

Csíkos, C., \& Verschaffel, L. (2011). Mathematical literacy and the application of mathematical knowledge. In B. Csapó \& M. Szendrei (Eds.), Framework for diagnostic assessment of mathematics (pp. 57-93). Budapest: Nemzeti Tankönyvkiadó.

Depaepe, F., De Corte, E., \& Verschaffel, L. (2010). Teachers' metacognitive and heuristic approaches to word problem solving: Analysis and impact on students' beliefs and performance. ZDMMathematics Education, 42, 205-218.

English, L. D. (2003). Reconciling theory, research, and practice: A models and modelling perspective. Educational Studies in Mathematics, 54, 225-248.

Fan, L., Xiong, B., Zhao, D., \& Niu, W. (2018). How is cultural influence manifested in the formation of mathematics textbooks? A comparative case study of resource book series between Shanghai and England. ZDM Mathematics Education, 50, 787-799.

Fonseca, B. A., \& Chi, M. T. (2011). Instruction based on self-explanation. In R. E. Mayer \& P. A. Alexander (Eds.), Handbook of research on learning and instruction (pp. 296-321). New York: Routledge.

Greer, B. (1997). Modelling reality in mathematics classrooms: The case of word problems. Learning and Instruction, 7, 293-307.

Hill, H. C., Ball, D. L., \& Schilling, S. G. (2008). Unpacking pedagogical content knowledge: Conceptualizing and measuring teachers' content-specific knowledge of students. Journal for Research in Mathematics Education, 39, 372-400.

Howson, A. G. (1980). Socialist mathematics education: does it exist? Educational Studies in Mathematics, 11, 285-299.

Hungarian Academy of Sciences-Committee on Mathematics Education. (2016). A tanítói/tanári kérdőívre beküldött válaszok összesitése [Summary of the answers to the teachers' questionnaire]. https://mta.hu/data/dokumentumok/iii_osztaly/2016/tanitoi_tanar i_kerdoiv_osszegzes_2016\%20(1).pdf.
Lehotanová, B. (2013). Matematika az alapiskolák 1. osztálya számára 2. rész. [Mathematics for the 1st grade of the elementary school: 2nd Part]. Bratislava: AITEC Kiadó.

Moro, M. I., Volkova, S. I., \& Stepanova, S. V. (2011). Математика часть 1. [Mathematics Part 1]. Москва: Просвещение. [Moscow: Prosveshcheniye].

Neményi, C., \& Szendrei, E. (1997). Szöveges feladatok [Word problems]. Budapest: Budapesti Tanítóképző Főiskola.

OFI. (2016). Matematika 1. osztályosoknak. I. kötet. [Mathematics for the 1st grade of the elementary school] (Vol. 1). Budapest: Oktatáskutató és Fejlesztô Intézet.

Olkun, S., \& Toluk, Z. (2002). Textbooks, word problems, and student success on addition and subtraction. International Journal of Mathematics Teaching and Learning. http://www.cimt.org.uk/ journal/olkuntoluk.pdf.

Palm, T. (2006). Word problems as simulations of real-world situations: A proposed framework. For the Learning of Mathematics, 26, 42-47.

Pehkonen, E. \& Pietilä, A. (2003). On relationships between beliefs and knowledge in mathematics education. Retrieved from: http:// www.dm.unipi.it/ didattica/CERME3/proceedings/Groups/TG2/ TG2_pehkonen_cerme3.pdf.

Pollak, H. O. (1969). How can we teach applications of mathematics? Educational Studies in Mathematics, 2, 393-404.

Pólya, G. (1945). How to solve it-A new aspect of mathematical method. Princeton: Princeton University Press.

Rowland, T., Huckstep, P., \& Thwaites, A. (2005). Elementary teachers' mathematics subject knowledge: The knowledge quartet and the case of Naomi. Journal of Mathematics Teacher Education, $8,255-281$

Shulman, L. S. (1986). Those who understand: Knowledge growth in teaching. Educational Researcher, 15, 4-14.

Stigler, J. W., Fuson, K. C., Ham, M., \& Sook Kim, M. (1986). An analysis of addition and subtraction word problems in American and Soviet elementary mathematics textbooks. Cognition and Instruction, 3, 153-171.

van Zanten, M., \& van den Heuvel-Panhuizen, M. (2018). Opportunity to learn problem solving in Dutch primary school mathematics textbooks. ZDM Mathematics Education, 50, 827-838.

Verschaffel, L., De Corte, E., \& Borghart, I. (1997). Pre-service teachers' conceptions and beliefs about the real-world knowledge in mathematical modelling of school word problems. Learning and Instruction, 7, 339-359.

Verschaffel, L., De Corte, E., \& Lasure, S. (1994). Realistic considerations in mathematical modeling of school arithmetic word problems. Learning and Instruction, 4, 273-294.

Verschaffel, L., Van Dooren, W., Greer, B., \& Mukhopadhyay, S. (2010). Reconceptualising word problems as exercises in mathematical modelling. Journal für Mathematik-Didaktik, 31, 9-29.

Vidákovich, T., \& Csapó, B. (1998). A szövegesfeladat-megoldó készségek fejlödése [The development of word problem solving skills]. In L. Varga (Ed.), Közoktatás-kutatás 1996-1997 (pp. 246-263). Budapest: Mûvelődési és Közoktatási Minisztérium.

Willis, G. B., \& Fuson, K. C. (1988). Teaching children to use schematic drawings to solve addition and subtraction problems. Journal of Educational Psychology, 80, 192-201.

Publisher's Note Springer Nature remains neutral with regard to jurisdictional claims in published maps and institutional affiliations. 